\title{
Need Analysis for Air Conditioners in Public Sector of Surabaya City Government
}

\author{
Dwiarti Larasputri and Maria Anityasari \\ Industrial Engineering, Faculty of Industrial Technology, Institut Teknologi Sepuluh Nopember (ITS) \\ Jl. Arief Rahman Hakim, Surabaya 60111 Indonesia \\ e-mail: m_anityasari@yahoo.com.au
}

\begin{abstract}
In typical buildings, air conditioners have the biggest percentage in energy consumption among all sectors. It makes a good management for air conditioners is needed and important in order to use the energy efficiently. Having a very hot and humid weather, it gives impact that most of buildings in Surabaya installed air conditioners, including Surabaya City Government office buildings. However, there is no regulation nor guidance how to manage air conditioners in Surabaya City Government, while Surabaya itself has a goal to become a green-eco city. Then, the existing condition of air conditioners usage in Surabaya Government units (SKPDs) needs to be evaluated. The evaluation will be based two different concepts, there are cooling load calculation and energy consumption intensity of green building. The result of the evaluation will be analyzed to know the real condition of air conditioners usage in Surabaya City Government.
\end{abstract}

Keywords - Air Conditioner, Green Building, GBAA Criteria Need Analysis.

\section{INTRODUCTION}

$\mathrm{E}^{\mathrm{s}}$ NVIRONMENTAL issue is the current topic in the world nowadays. Environmental impacts are always considered together with the rapid development in many sectors. It is occurred because the development such as the population growth, the technology advancement, or the expansion of business, will always be related to energy consumption and give impact to the environment. The development of a country also sometimes be defined by looking at the infrastructure improvement and the increase of urban buildings.

Not only they contribute a lot for the energy consumption, but buildings also emit about one-third of greenhouse gas emissions in the world. As it can be seen on Figure 1.1, buildings have the highest percentage, which is $38 \%$, as the contributor of GHG emissions from fossil fuels. The number is more than both the transportation and industrial sectors which are known clearly producing emissions. The emissions of buildings come from the combustion of fossil fuels to provide heating, cooling and lighting, and to power appliances and electrical equipment [1].
GHG Emissions from Fossil Fuels

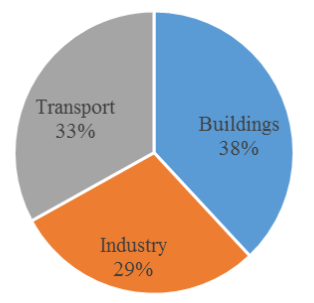

- Buildings $\quad$ - Industry $\quad$ Transport

Figure. 1 Contributors of GHG from Fossil Fuels (USGBC, n.d.)

Sustainable building, or is commonly known as green building, is the practice of creating structures and using processes that are environmentally responsible and resourceefficient throughout a life cycle of building [2]. Priatman [3] stated that green building is specifically a design structure that reduces overall negative impact that is caused by the built environment. From those definitions, green building has strength in environmental and energy aspects compared to common buildings.

Surabaya, as the second largest city in Indonesia, is an industrial city that is always growing and improving. Being led and organized by a visionary city mayor, Surabaya has an objective to become a green eco-city. After implementing the initial step by building many public parks around the city, Surabaya wants to apply green building concept as the next step of becoming an eco-city. Looking at the city development, green building seems to become an urgency for Surabaya to be applied.

Eventually, in 2014, Surabaya City Government held Green Building Awareness Award (GBAA) [6]. It was aimed to increase the awareness of the building owners and residents in Surabaya about environmental issues caused by buildings. In this event, 177 buildings were rated and judged to choose 12 winners for 4 categories. Those categories were hotels, apartments, malls, and office buildings After the GBAA finished, in 2015, the city mayor of Surabaya, Tri Rismaharini, mentioned that buildings in Surabaya have to follow green building principles. The city mayor also wanted that Surabaya government offices also implement this green building.

However, green building has many aspects that makes the whole implementation is quite complicated to be done directly at a time. Then, the implementation is narrowed into applying green building into the air conditioners usage. HVAC, which stands for heating, ventilating, and air conditioning, has the highest percentage among all. Thirty percent of this energy consumption spends for heating and 
cooling the rooms in building [5]. It means that by managing the usage of air conditioners, it can reduce the energy consumption which is included in the green building principle.

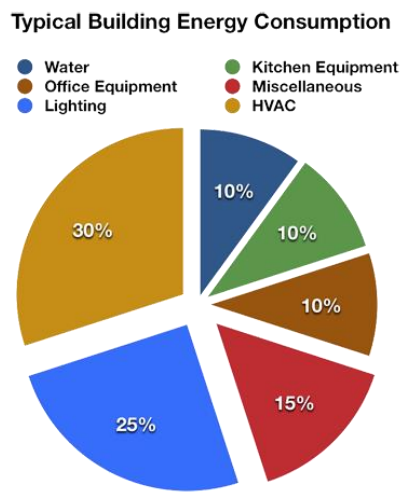

Figure. 2 Energy Consumption Percentage in Typical Building (Burger, 2015)

Surabaya, with the weather really hot and humid, has the increasing number of air conditioner every year. In Surabaya City Government, each unit or called as Satuan Kerja Perangkat Daerah (SKPD) can have around 20-100 air conditioners. It is a large number for Surabaya City Government in managing numerous air conditioners. Therefore, the maintenance of the air conditioners is loose and the usage of air conditioners cannot be monitored well. The asset of air conditioners also has routine maintenance, but not all SKPDs record it and update the condition. The current management of air conditioners in Surabaya City Government needs to be evaluated and analyzed in order to implementing better management with green building concept.

The limitation used is that the research is only focused on office buildings. Badan Perencanaan Pembangunan Kota (Bappeko) is a government unit that is usually used for benchmarking by other SKPDs. According to Sistem Informasi Manajemen Barang Daerah (SIMBADA), Bappeko is one of SKPDs that has increasing cumulative number in air conditioners [6]. In addition, it is also where the pilot project of green building takes place. Therefore, this final project conducted the pilot study of green building at Bappeko office building located at Jalan Pacar No. 8, Surabaya.

\section{RESEARCH METHODOLOGIES}

There are several steps to conduct this research, which are:

a) Data Collection

All data related to air conditioners usage in Surabaya City Government are collected. The initial data is from SIMBADA which is verified by survey and interview. Direct measurement for office rooms is also conducted to obtain the data of room dimension.

b) Evaluation Analysis of Existing Condition

The data that have been collected are processed to be evaluated. The evaluation is based on cooling capacity calculation and energy efficiency standard of green building.

c) Development of Ideal Condition based on GBAA Criteria
The ideal condition is formed by the gap between the existing condition and the standards.

d) Determination of Factors that Influence the Need of Air Conditioners in Surabaya City Government

In this step, there will be some interviews with the person in charge of air conditioners asset in the SKPD. Then, the result will be combined with the existing condition to determine the factors.

e) Development of Air Conditioners Need Analysis Procedures

The result of the previous step will be the reference in making an air conditioners need analysis procedures.

f) Conclusions and Suggestions

The conclusion can be taken as the result of the analysis to answer the defined objectives of the research. Then, the recommendation is made to be offered for Surabaya City Government and also for the development of the next research.

\section{EVALUATION OF EXISTING CONDITION}

\section{A. The Existing Condition of AC Usage Manaement}

The usage of air conditioners in Bappeko is not monitored well because there is no regulation about it. The users of the air conditioners, - in this case, the users are employees in Bappeko -, are also not acknowledged to use the air conditioners optimally. Daily, the air conditioners are turned on the whole day during the working hours. The users operate air conditioner on the temperature they are desired, whereas there is actually a regulation that the air conditioner should be turned on between $24-27{ }^{\circ} \mathrm{C}$ due to the energy saving. Some AC remote controllers also have broken display monitor, so that the temperature itself cannot even be identified.

Related to the usage of air conditioner, the staff of the asset management staff in Bappeko, air conditioners have routine cleaning and maintenance once per 4 months. However, it is never recorded when the exact date of cleaning and maintenance was along with the latest condition checked. This data is quite important for decision making in the future. If the air conditioner is out of order, this data will be helpful to determine whether that air conditioner should be replaced or only needs to be repaired. This kind of decision making is also related to the age or the lifetime of air conditioners which is not monitored either. There are some air conditioners that are already more than 10 years, but it is not recorded whether it is still in good condition or ever given special maintenance or so on.

\section{B. Evaluation Analysis of the Existing Condition}

Cooling load is the amount of heat load in a room or in a building that needs to be cooled. By having air conditioners with suitable cooling capacity, the room will be cooled in the normal speed. The comfort of the users inside the room can also be built. In the calculation, this cooling capacity is influenced by the number of people inside the room, the lamps in the room, and especially the size of the glass window. The higher the number of people who occupy the room, the more lamps in the room, and the wider size of glass window can increase the cooling needed in the room. It means that it needs air conditioner with higher capacity. 
The method that is used to calculate the cooling load of rooms in Bappeko is from the book entitled Panduan Sistem Bangunan Tinggi [8]. The formulations that are used to calculate the cooling load are listed below.

\section{Building Sensible Load}

Sensible heat is the type of heat that can be measured by a thermometer and felt by our skin. Building sensible load (BSL) is the sensible heat that is owned by the building itself. The heat is kept in the wall and is influenced by the four cardinal directions which are west, north, east, and south. The material of the wall also affect the heat produced. In this case, the material of wall is limited into two, the stone and the glass (window). The formulation to calculate BSL is shown below.

\section{$B S L=$ Room Area $x$ Heat Load}

(Formulation 2.1)

The heat load is different for each wall. It depends on the material and the direction it faces.

Table 1

Heat Load

\begin{tabular}{lc}
\multicolumn{2}{c}{ Heat Load } \\
\multicolumn{2}{c}{ Heat Load $\left(\mathrm{BTU} / \mathrm{hr} / \mathrm{m}^{2}\right)$} \\
\hline Glass & \\
North Side & 800 \\
South Side & 400 \\
East Side & 900 \\
West Side & 1000 \\
Wall & \\
North Side & $2.15 *\left(\mathrm{t}_{0}-\mathrm{t}_{1}\right)$ \\
South Side & $2.15 *\left(\mathrm{t}_{0}-\mathrm{t}_{1}\right)$ \\
East Side & $2.15 *\left(\mathrm{t}_{0}-\mathrm{t}_{1}\right)$ \\
West Side & $2.16 *\left(\mathrm{t}_{0}-\mathrm{t}_{1}\right)$ \\
\hline \hline Note: For Indonesia, $\left(\mathrm{t}_{0}-\mathrm{t}_{1}\right)=5^{\circ} \mathrm{C}\left(\mathrm{Juwana}_{1}, 2008\right)$
\end{tabular}

\section{Internal Heat Load}

Internal heat load is the heat that comes from the human and the equipment inside the room. In this calculation, the equipment is limited only for the lamp.

\section{1) Occupancy}

The occupancy of a room is determined by number of people in the room. In Bappeko, the occupancy means the number of employees in a room.

2) People Sensible Load (PSL)

The sensible heat load of people can be calculated by the formula below.

$$
P S L=\text { Occupancy } x 200
$$

(Formulation 2.2)

3) People Latent Load (PLL)

The latent heat load of people can be calculated by the formula below.

$$
P L L=\text { Occupancy } x 250
$$

(Formulation 2.3)

4) Lamp Sensible Load (LSL)

The sensible heat load of lamp can be calculated by the formula below.

$$
L S L=\left(\sum w a t t\right)(1.25) \times(3.4)
$$

(Formulation 2.4)

\section{Ventilation and Infiltration Load}

1) Infiltration Load $\left(\mathrm{CFM}_{1}\right)$

The formulation of infiltration load is shown below.

$$
C F M_{1}=\frac{l \times w \times h \times A C R \times(35.31)}{60}
$$

(Formulation 2.5)

2) Ventilation Load $\left(\mathrm{CFM}_{2}\right)$

The formulation of ventilation load is shown below.

$$
C F M_{2}=\left[\left(t_{0}-t_{1}\right) \times 1.08+\left(R H_{0}-R H_{1}\right) \times 0.67\right]
$$

(Formulation 2.6)

For Indonesia, $\left(\mathrm{t}_{0}-\mathrm{t}_{1}\right)=5^{\circ} \mathrm{C} . \mathrm{RH}_{0}$ is the outdoor humidity and $\mathrm{RH}_{1}$ is the indoor humidity.

\section{Cooling Load (CL)}

The cooling load of a room can be calculated by the total of all three heat loads which is shown in the detail formulation below. All units are in BTU/hr. $\mathrm{CL}=\mathrm{BSL}+\mathrm{PSL}+\mathrm{PLL}+\mathrm{LSL}+\mathrm{CFM}_{1}+\mathrm{CFM}_{2}$

(Formulation 2.7)

From the result for the rooms in Bappeko, it is shown that most of rooms exceeded the normal cooling load. For example, for normal condition, the cooling capacity only needs $1032.40 \mathrm{BTU} / \mathrm{h}$ but the room has the capacity of 9000 $\mathrm{BTU} / \mathrm{h}$. The difference is quite big then it actually makes the current air conditioner is over capacity. It also occurs to other rooms. Overcapacity in using air conditioner will lead into wasting the energy, because actually the energy that is spent can be lower than that.

However, it also means that the cooling capacity has been fulfilled and the employees inside each room are expected to be comfortable. The room should be cool enough or even it will make the room more chilled. Then, there is no reason to add or purchase new air conditioner because the cooling need has been fulfilled.

After it is known that the cooling need of most rooms are fulfilled, further analysis should be conducted whether the existing air conditioners already use the energy efficiently. If the energy consumption intensity is lower than 100.8 $\mathrm{kWh} / \mathrm{m}^{2} /$ year, the usage of air conditioners can be categorized as efficient [7]. On the other hand, if it is more than $100.8 \mathrm{kWh} / \mathrm{m}^{2} /$ year, it is already less efficient. Furthermore, if the ECI is higher than $133.2 \mathrm{kWh} / \mathrm{m}^{2} /$ year, it is categorized as not efficient.

Table 2

Standard of ECI for Air Conditioner usage in Government Office Buildings

\begin{tabular}{lc}
\hline \multicolumn{1}{c}{ Criteria } & $\begin{array}{c}\text { AC Energy Consumption } \\
\left(\mathrm{kWh} / \mathrm{m}^{2} / \text { year }\right)\end{array}$ \\
\hline Very Efficient & $<61.2$ \\
Efficient & $61.2-100.8$ \\
Less Efficient & $100.8-133.2$ \\
Not Efficient & $>133.2$ \\
\hline \hline
\end{tabular}

Based on the standards mentioned, it is shown that not all existing air conditioners are efficient in using energy. For example, the air conditioner with 794 watt of input power is categorized as not efficient for Head of Environment and Spatial Sub Department room. It should use air conditioner with lower input power or an eco-friendly one. There are 10 of 27 rooms in Bappeko which are categorized as not effective and 2 rooms are categorized as less effective. The rooms may be comfortable for the users - in this case, the users are employees in Bappeko - because the required cooling capacity is already covered by the existing air 
conditioners, but it is not in line with the green building. Very efficient rooms in Bappeko are influenced by the usage of its rooms. The rooms categorized as very efficient are mostly meeting rooms. It is because the rooms are not used for the whole working hours, just once in a while when the meeting is conducted. The duration of the meeting is also not taking the whole day. Typically, it is finished for 2 until 3 hours.

In addition, the behavior of users and the maintenance frequency also affect the energy efficiency in using air conditioners. If the air conditioners are well-monitored and given routine maintenance, their lifetime will be long and still be functioning well. The increasing of the energy consumption should be the indicator that the air conditioners need to be repaired or even be replaced. However, if the current air conditioners already consume big energy, the increasing of the energy consumption cannot be the indicator. With this existing condition, the need of air conditioners in Bappeko is fulfilled and there should be no reason to add them more.

\section{CONCLUSION AND SUGGESTION}

The existing condition of air conditioners usage in Bappeko is still not organized and maintained well. Most of the usage of air conditioners in Bappeko exceeds the necessary cooling capacity. It means that the cooling need is mostly fulfilled, but based on the standards from GBAA criteria, it is shown the energy usage is not all efficient. It is caused by the behavior of the user which is not controlled and the management of air conditioners is still not structured.

The Surabaya City Government, especially Bappeko where this pilot research taken place, needs to have the record of existing condition, both for the condition of the room and the air conditioners, and update it once in a while. The record of air conditioners maintenance is highly suggested.

\section{REFERENCES}

[1] USGBC, (n.d.). Buildings and Climate Change. 1st ed. [ebook] EESI, pp.1-2. Available at: http://www.eesi.org/files/climate.pdf [Accessed 18 Apr. 2016].

[2] EPA, (2016). Green Building. [online] US Environmental Protection Agency. Available at: https://archive.epa.gov/greenbuilding/web/html/ [Accessed 17 Apr. 2016].

[3] Priatman, J. (2016). Green Building Principles \& Implementation (Surabaya case-study).

[4] Listyanti, A. (2014). Surabaya Gelar Green Building Awareness Award 2014. Tempo. [online] Available at: https://m.tempo.co/read/news/2014/09/11/058606178/surabayagelar-green-building-awareness-award-2014 [Accessed 18 Apr. 2016].

[5] Burger, A. (2015). Falling Costs, VCs Fuel Surge in Building Energy Management Services. [online] Global Warming is Real. Available at: http://globalwarmingisreal.com/2015/10/13/falling-costs-vcsfuel-surge-building-energy-management-services/ [Accessed $16 \mathrm{Apr}$ 2016].

[6] Simbada Surabaya (2016). Sistem Informasi Management Barang Pakai Habis - Pemerintah Kota Surabaya - 2015. [online] Available at: http://simbada.surabaya.go.id/ [Accessed 18 Feb. 2016].

[7] USAID, (2014). Panduan Penghematan Energi di Gedung Pemerintah. 1st ed. [ebook] Jakarta, pp.15-16. Available at: http://www.iced.or.id/wp-content/uploads/2015/11/PanduanPenghematan-Energi-di-Gedung-Pemerintah.pdf [Accessed 27 Jun. 2016].
[8] Juwana, J. (2008). Panduan Sistem Bangunan Tinggi. Jakarta: Erlangga, pp.123-127. 